\title{
Occurrence of the genus Pterobryopsis M.Fleisch. (Pterobryaceae) in Brazil
}

\author{
DENILSON FERNANDES PERALTA ${ }^{1,3}$ and SILVANA B. VILAS BÔAS-BASTOS ${ }^{2}$
}

(received: September 22, 2010; accepted: January 20, 2012)

\begin{abstract}
Occurrence of the genus Pterobryopsis M.Fleisch. (Pterobryaceae) in Brazil). The species Pterobryopsis stolonacea (Müll. Hal.) Broth. had been cited as occurring in southern South America but had not been previously reported for Brazil. This is an important finding in terms of the Brazilian bryophyte flora. Descriptions and illustrations are presented.
\end{abstract}

Key words - Atlantic forest, new record, range extension

\section{INTRODUCTION}

Pterobryaceae is a family of mosses with tropical distributions and robust gametophytes that occur in America, Africa, Oceania, and Asia, where, according to Argent (1973), it reaches its maximum diversification. Ten genera and 35 species are found in the Neotropics, (Gradstein et al. 2001), 15 of which are widely distributed in Brazil.

Yano (1996) cited the species Pterobryopsis ulei (Müll. Hal.) Fleisch. but in the same work cited the basyonym Garovaglia ulei Müll. Hal. as a synonym of Jaegerina scariosa (Lor.) Arzeni, making the current citation the first real record of the genus Pterobryopsis in Brazil.

\section{MATERIAL AND METHODS}

While examining samples of Pterobryaceae during the preparation of the Guide to the Mosses of Brazil (in progress) we encountered an interesting record of Pterobryopsis stolonacea. Analyses of the distribution range of this taxon indicated that this record would be expected, but there had been not a single citation of any specimen in Brazil.

\section{RESULTS}

Pterobryopsis stolonacea (Müll. Hal.) Broth., Natürl. Pfl. I(3): 803. 1906. $\equiv$ Pterobryon stolonaceum Müll.Hal., Linnaea 42: 423. 1879. Type: Argentina: Argentinia

1. Instituto de Botânica, Caixa Postal 68041, 04045-972 São Paulo, SP, Brazil.

2. Universidade Federal da Bahia, Instituto de Biologia, Depto. de Botânica, Laboratório de Taxonomia de Briófitas. Campus de Ondina, Rua Adhemar de Barros 500, 40170-110 Salvador, BA, Brazil.

3. Corresponding author: denilsonfp@yahoo.com.br subtropica, Alto de las Capillas prope Jujui, inter Pilotrichellam, Orthostichella cyathipoma nuncupatam, 28-III-1873, sterilis, PG Lorentz s.n. (H-BR).

Figure $1 \mathrm{a}-\mathrm{h}$

Description. Plants medium-sized, dark-green to yellow-green, 50-100 mm long, forming tufts. Primary stems creeping, leaves oblong triangulate, 10-12 mm long, inconspicuous; secondary stem erect, leaves imbricate, oblong, 150-200 mm long; branches irregularly pinnate, leaves imbricate, oblong, 100-120 mm long. Laminar cells rhomboidal-fusiform, $15-20 \times 10-15 \mu \mathrm{m}$, alar cells square, $15-20 \times 10-15 \mu \mathrm{m}$, thick-walled, plane margins, denticulate, not bordered, costa narrow $1 / 5-1 / 3$, percurrent. Propagula in branch leaf axils, cylindrical to elliptical. Sporophyte not seen.

Specimen examined: BRASIL. São PAUlo: Águas da Prata, sobre raízes tabulares de Ficus sp., 17-III-1983, O Yano \& DP Santos 6138 (SP); idem, $8000 \mathrm{~m}$ alt., 26-V1986, A Schäfer-Verwimp \& I Verwimp 7085 (SP). MinAS GERAIS: São Tomé das Letras, sobre tronco de árvore, mata, 18-XII-2008, O Yano \& M Kirizawa 31375 (SP).

Distribution. Argentina, Bolivia, Peru, and Brazil (new Brazilian records in the states of São Paulo and Minas Gerais).

Habitat. Grows on the bark of trees in deciduous forests in the Atlantic Forest Biome, at ca. 700-8,000 m alt., the same elevation reported for the genus in the Neotropics according to Gradstein et al. (2001).

\section{DISCUSSION}

According to Gradstein et al. (2001), two species of Pterobryopsis occur in the Neotropics: P. mexicana (Renauld \& Cardot) M.Fleisch. and P. stolonacea, although they are morphologically very similarity 


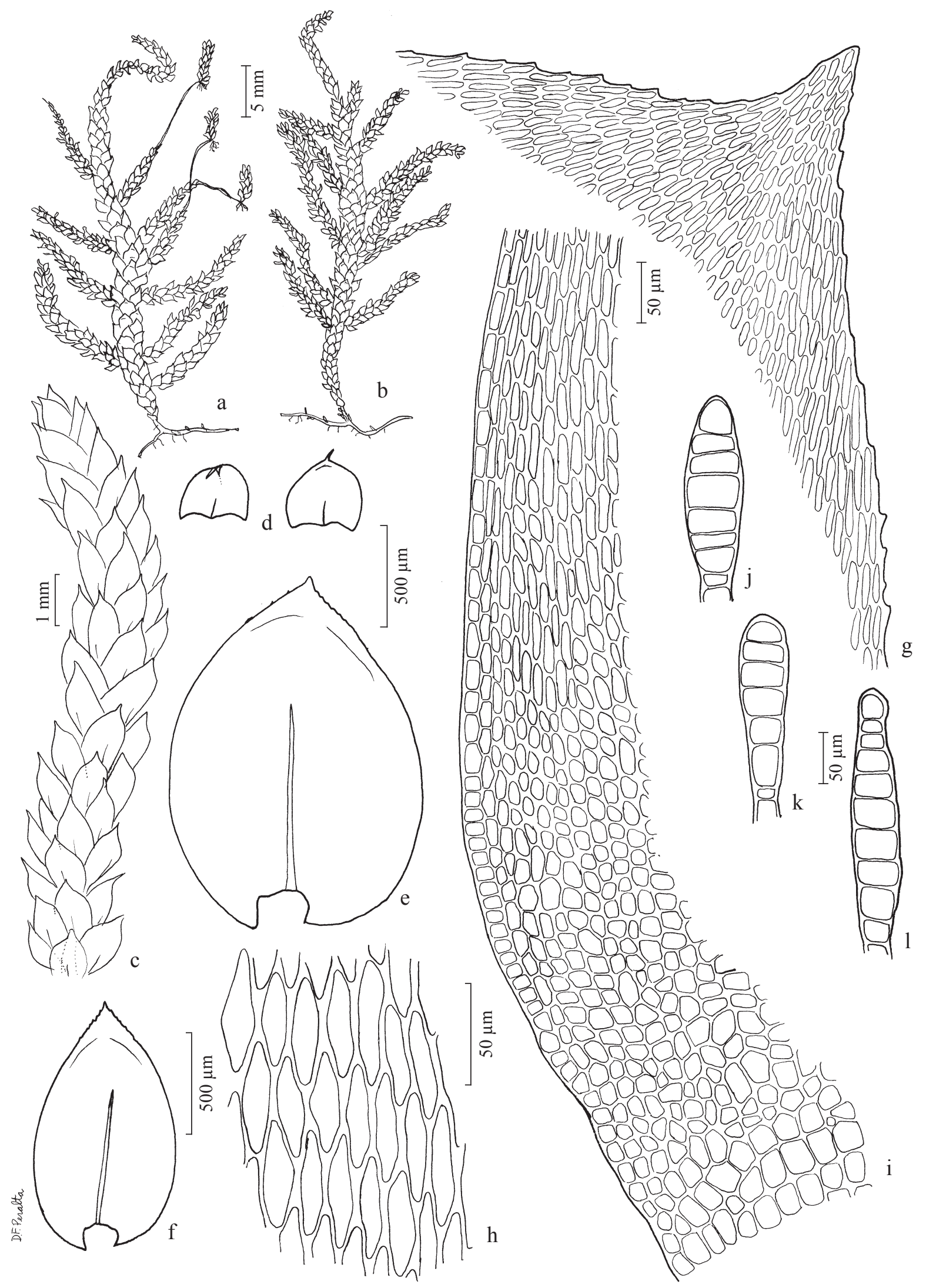

Figure 1. Pterobryopsis stolonaceae. a-b. Habit. c. Portion of secondary stem. d. Stem leaves. e. Secondary stem leaf. f. Branch leaf. g. Leaf apex. h. Laminal cells, midleaf. i. Basal marginal cells. J-1. Propagula (O Yano \& M Kirizawa 31375). 
(Magill 1994). The range of $P$. mexicana is restricted to Mexico and Central America, and that of P. stolonacea to South America (being cited as probable to southeastern Brazil by Gradstein et al. 2001).

This is the first record of the specie P. stolonacea for Brazil. This species is common in southern South America and, according to these new records, appears to have a wider distribution than previously reported.

After a detailed study of the specimens and bibliographic records, we discovered that the difference between the two Neotropical species $P$. mexicana and $P$. stolonacea is the shape of the leaves on the principal stem. Arzeni (1954) described these leaves as lanceolate in P. mexicana and triangular-ovate in P. stolonacea.

As the shapes of the leaves on the principal stem are useful in characterizing the different taxa in the Pterobryaceae, their morphology indicates that these Brazilian specimens represent $P$. stolonacea.

The character of leaf shape may be not sufficient to maintain these two taxa as distinct species, as their distribution ranges are very close and the environmental conditions where they occur are likewise very similar. Additional studies of this genus will be necessary to determine more useful and definitive characteristics to distinguish these two species.

\section{REFERENCES}

Argent GCG. 1973. A taxonomic study of African Pterobryaceae and Meteoriaceae I. Pterobryaceae. Journal of Bryology 7:353-378.

Arzeni CB. 1954. The Pterobryaceae of the Southern United States, Mexico, Central America, and the West Indies. American Midland Naturalist 52:1-67.

Gradstein SR, Churchill SP, Salazar-Allen N. 2001. Guide to the Bryophytes of Tropical America. Memoirs of The New York Botanical Garden 86:1-577.

Magill RE. 1994. Pterobryaceae. In Moss Flora of Mexico (AJ Sharp, H Crum, PM Eckel, eds.). Memoirs of The New York Botanical Garden 69:705-718.

Yano O. 1996. A checklist of Brazilian bryophytes. Boletim do Instituto de Botânica 10:47-232. 